\title{
TORE ERIKSEN: ANTROPOLOGIEN OG DEN MODERNE HISTORIE
}

En indgang til O. Negt \& A. Kluge: Geschichte und Eigensinn.

\begin{abstract}
"Når Hegel taler om at "virkelighedens brogede bark" må gennembrydes, så går han derved ud fra, at fremtrædelserne, den empiriske virkelighed, sådan som den giver sig, er porøs. At erkende denne porøsitet på baggrund af processer, som endnu ikke har karakter af færdige resultater, er en væsentlig opgave for teorien. Hvor den ikke opfylder denne opgave, viser der sig stadig aporier, udvejsløsheder, for en forskning, der er indskrænket til den ligefremme empiri. Det, som arbejder i undergrunden, som noget latent, som tendens, der trænger frem til realiteten, men som endnu ikke har nogen egen udtryksformåen, bliver tit overset i sådanne empiriske undersøgelser. Det historisk virksomme er imidlertid ikke sjældent netop indeholdt $i$ disse latente processer og ikke i de, som viser sig i ydre form, i realitetens hårde gestaltning, som anskuelig beton".
\end{abstract}

Geschichte und Eigensinn ( $G$ \& E) s. 481

\section{DET "MODERNISTISKE" STILELEMENT}

Mangfoldig, kalejdioskopisk, aforistisk, uendelig, usammenhængende, billedrig, vilkårlig osv. Mange er de etiketter, man kunne sætte på Negt/ Kluges nye bog. Og ligesom formen, er også intentionen tilsvarende uambisiøs og uakademisk. Eller mon?

Et fremtrædende træk ved G \& E er den konsekvente mangel på en samlet overordnet metodisk redegørelse for det foreliggende arbejde og alligevel sidder man med en følelse af, at de ikke foretager sig andet. De lægger sig ikke fast på nogen bestemt teoretisk position, hvorfra de kan udslynge en velorganiseret problematik, et relevant materiale og et veldefineret genstandsområde. Og alligevel er der en problematik, som hele tiden lurer i kulisserne; en bestemt intention og et bevidst perspektiv. En symtomal "mangel", der ikke er helt udvendig til "sagen selv".

Måske ligger der en vis erkendelsesteoretisk "pessimisme" heri - efter de store teorikonstruktioners tid! Men denne "pessimisme" betyder ik- 
ke nødvendigvis en passiv resignation eller defaitistisk undergangstone. Så havde man hellere holdt sin kæft. Langt snarere synes den hos $\mathrm{N} / \mathrm{K}$ at være motiveret $i$ en tidstypisk og eksistentielt oplevet dynamik og uregerlighed i selve den intellektuelle produktion; den kommer aldrig til noget hvilested, hvorfra man kan overskue, redegøre for endsige udfolde en fyldestgørende ideologikritisk demaskering af diverse ideologemers hævden og gøren.

Slægtskabet til Hegel er ikke til at komme fra. Ikke blot den faustiske rastløshed, men også det afvisende forhold til en resignativ pessimisme eller ekspticisme synes de at have arvet. Overfor en position, der tror at kunne begribe det absoluttes mange momenter $i$ et blitz og ikke i dets erfaringsdialektiske bevægelse - og som derfor, straks den når frem til et begrebs modsigelsesfylde, må opgive det for så at begynde forfra på et helt andet sted - og hvorigennem intet er begrebet - dér stiller Hegel en reflekteret eller produktiv skepticisme, der driver modsætningerne til det yderste, ikke for at opgive tanken ved denne yderste rand, men ved at begribe disse modsætninger som tankens egen bevægelse.

Med Hegels begrebshypostase, hvor begrebet er sagen og det Enkelte lader sig fange i det Almenes medium, da dukker der imidlertid op en illusion om, at der hinsides modsætningen gives en positiv forsoning. Denne optimistiske illusion afføder et teleologisk fremdriftsmoment i den hegelske diskurs, der terminerer i den absolutte ånd, hvor alle modsætninger har funder deres forsoning, idet ånden kommer til den fulde bevidsthed om sig selv.

Herved er fjendskabet til Hegel heller ikke til at komme fra - og Frankfurter-ånden melder sig. Hos Adorno er det præcis dette teleologiske moment, der er fraværende. Den tankebevægelse, som her er på spil, er ikke diskursiv og fremadrettet mod et bestemt mål; tyngdepunktet er lige nærværende overalt $i$ teksten. Hans stil er en prismatisk fremstillingsform, en kredsen omkring et teoretisk gravitationsfelt, der udslynger og organiserer genstandsfelterne. Den samme problematik gennemspilles $i$ et mangefacetteret og righoldig materiale, der ikke peger i nogen bestemt retning, omend den er organiseret ud fra en bestemt erkendelsesinteresse; det paradoksale forsøg på at "undsige det uudsigelige", det ikke-identiske, der falder udenfor sprogets og tænkningens medium. Mere end nogen anden er Adorno et kardinaleksempel på en pessimisme eller skepticisme, som ikke er resignativ, og som gennem en kritik af tænkningen ikke prisgiver den.

En sådan pessimisme kan udmærket godt betyde en øget intellektuel 
produktivitet, en vis fandenivoldsk holdning midt i udsigtsløsheden; når det absolut velfunderede teoretiske (eller eksistentielle) standpunkt ikke længere findes, så kan man først frisætte videbegæret uden at bekymre sig om, hvorvidt "resultatet" bliver fragmenteret og usystematisk.

$\mathrm{P} \stackrel{\circ}{\text { den }}$ anden side lader det sig ikke gøre at idenfiticere positionen med den gammelkendte attituderelativisme, hvorved alle teoretiske udsagns signifikans og sandhed ækvivaleres, hvor alle katte bliver grå (undtaget attituderelativistens egen metafilosofi, der opkaster sig til den nye - intetsigende - sandhed). Uudtalt, men ikke desto mindre operativt, ligger der bestemte snitflader, teoretiske tyngdepunkter, bestemte erkendelsesinteresser, stoflige udvælgelseskriterier og metodiske inspirationskilder i deres forehavende.

Det uudtalte består ikke så meget i en fortielse eller underkendelse af egne forudsætninger og rammer, men langt snarere $i$ en uforpligtethed overfor et diktum om, at trådene skal samles og syntetiseres i et helhedligt, metodisk paradigme. De eksercerer rundt i vidt forskellige teoretiske traditioner og positioner, foruden at inddrage impirisk materiale fra et utal af enkeltvidenskaber og det uden at tage forbehold eller kritisere de problematiske sider ved de pågældende teorier og videnskaber.

I N/K's bog bliver man tvunget til at læse fodnoter, revearseltekst, indrammede spalter, indledende forbemærkninger, billedmateriale og brødtekst med den samme opmærksomhed. Selve organiseringen af stoffet angiver få pegefingre til en umiddelbar hierarkisering og ordning og den fortløbende skrivestil (der for det meste hænger sammen via associative knudepunkter), smadrer enhver klassisk fremstilling. Kapitelinddelinger og overskrifter må ikke tages alvorligt.

Uforpligtetheden synes herigennem at få en alvorlig slagside; nemlig vilkårligheden i receptionen af deres projekt. Nu kan man selvfølgelig aldrig sikre sig mod, at Fanden læser Bibelen; at enhver læsning implicerer vilkårlighed, p.g.a. andre forudsætninger og intentioner. Skrivestilen er imidlertid ikke så meget begrundet $i$ denne banalitet, men mere $\mathrm{i}$ det forhold, at det skal være en "brugsbog", hvor man forventer en "egeninteresse hos læseren, idet han udsøger de passager og kapitler, der har med hans liv at gøre. På denne måde opdeler bogen sig ret hurtigt. Der gives bøger, som man læser fra begyndelsen til slut. Der gives også bøger, hvis dyd ligger i gentagbarheden ... Men ingen bog giver mere end en chance til at forholde sig selvstændigt." 
I den samme ånd er 'bogen' også undfanget; den modernistiske skrivestil er ikke et subjektivt 'hang-up', men betinget af en stadig mere uigennemskuelig virkelighed, hvor man tvinges til at improvisere.

Ingen af hovedteserne er hængt op på rigtigheden af de enkelte empiriske eksempler og iagttagelser. Det samme gælder også for fremdragelsen og afbenyttelsen af de mange forskellige teoretiske brudstykker. Glidningerne mellem de forskellige brudstykker, den nomadiske vandring fra ene scene til den næste, udtrykker på en og samme tid det produktive element, videbegæret, identitetsløsheden, brudfyldtheden og diskontinuitet. De lader sig ikke fastbinde til bestemte synspunkter eller perspektiver, og følgelig ville det også være absurd at kritisere dem ud fra principielle kritikker af de enkelte teoripositioner, som de betjener sig af. Uagtet andre konsekvenser og affiniteter har de i tekstmassen kun status af analogier og metaforer. De tjener mere til at suggerere og pejle læseren ind i nogle tankebaner, der kan bidrage til at synliggøre de menneskelige livs- og arbejdsevners skjulte strukturer end til at karakterisere et håndfast teoretisk ståsted. N/K gør brug af en arbejdsform, der selvfølgelig må afprøve de levende forhold som var de ting; de kan lægges ved siden af hinanden, tages fra hinanden, samles i nye konstallationer eller forfølges i deres spredning. I virkeligheden danner disse levende forhold eller selvreguleringssystemer flyvende love. I det teoretiske arbejde derimod er man tvunget til at foretage stiliserede beskrivelser. Teoriens arbejdsmidler, f.eks. analytiske distinktioner og perspektiveringer, oprettelse af elementardele og enheder, antagelser om årsagssammenhænge osv. medfører nødvendigvis, at man adskiller og fikserer processer, som i virkeligheden er i uophørlig bevægelse, og det uanset om man intentionelt ønsker eller forsøger at fange processerne i deres bevægelse.

Med reference til Levi-Strauss karakteriserer de deres arbejdsmåde som "fletværksbyggeri" (basteln), der indebærer, at man altid bygger noget af sig selv ind uden nogensinde at udfylde eller blive færdig med det. Det forholder sig med de menneskelige arbejdsevner som med fletværket eller myterne, forholdet mellem deres opstån og vor nutidsbevidsthed har lukket sig for én, og man kan aldrig blive færdig med dem, dvs. ikke skrive nogen udfyldende eller fuldendt beskrivelse af dem. De mangfoldiggør sig $i$ en uendelighed, og nogen patentsikker dechifreringsnøgle kan man aldrig komme i besiddelse af.

"Ligesom fletværket på det tekniske niveau kan også den mystiske tænkning på det intellektuelle niveau opvise glimrende og uforsigelige resultater. Omvendt har man ofte bemærket fletværkets myto-poetiske karakter. Myter- 
terne fordobler sig i det u'endelige. De besidder ingen evne til at rette sig efter det cartesianske princip. Derfor har de heller ingen udgrænsningsmekanismer ... Da en mythos består af helheder af alle sine varianter, må strukturanalysen betragte dem alle med det samme alvor."

G \& E s. 224, note 2

De enkelte arbejdsevners opståen, differentieren, regredering, sammenfletning osv. fortaber sig i en uendelighed og kan ikke rekonstrueres.

\section{AT SKRIVE OVER NEGT/KLUGE}

Problemlandskabet var der herværende skribleri kan bedst angives ved dets yderpoler.

$\mathrm{På}$ den ene side har man den klassiske antropologifigur eller den naturalistiske position, der abstrakt og overordnet kan beskrives som en forestilling om, at der i menneskets indre ligger en antropologisk kerne, et i mennesket iboende og uforanderlig væsen, der til syvende og sidst opfattes som det mest grundlæggende eller oprindelige. Denne autenticitet ligger så at sige under alle menneskets forskellige historiske fremtrædelsesformer som en uantastelig og invariabel kerne, der godt nok kan undertrykkes, men som igen kan dukke frem i sin jomfruelige tilstand, hvis blot mennesket ville afkaste sin historiske og samfundsmæssige (og evt. repressive) form. Denne eviggyldige sandhed er tillige den faste grund, der skulle muliggøre en kritik af menneskeundertrykkende tilstande. Den menneskelige Natur, der blot i kraft af at være 'naturlig', gør krav på at være en transcendental kritikmålestok og som sådan er et dualistisk modbegreb til Historien. Som klassisk emancipationskategori indenfor den borgerlige tænkning har dette fungeret som et tilforladelig filosofisk ståsted.

Anvendt indenfor videnskaberne har det åbenbart været mere problematisk. Historisk frembragte evner, kompetencer, attituder, adfærdsformer, institutioner, produktionsforhold osv. hales tilbage til naturkategorier, via en ahistorisk og naturvidenskabelig forståelsesoptik; tit i form af en biologisk reduktionisme, hvor det genuint historiske forbliver en ren kognitiv udsmykning. Den invariable biologiske substans og dens historiske fremtrædelsesform falder fra hinanden $i$ en udenpåklistret og stiv dualisme. I den grad, man har forsøgt at positivere denne antropologiske substans - og det sker som regel i form af en opremsning af uomgængelige fysiologiske betingelser for eksistensen - er det i bedste fald banaliteter og selvfølgeligheder. I værste fald bliver det en legiti- 
mation af bestemte borgerlig-historiske former ved at forestille dem som ahistoriske og universelle.

På den modsatte flanke i vort problemlandskab er der det, som kunnes kaldes en identitetsfilosofisk eller historicistisk position, der hævder den menneskelige natur som absolut plastisk; cier lader sig divedere op i sine samfundsmæssige bestemmelser, og som følgelig heller ikke ville kunne "gå på tværs" af den samfundsmæssige formning i form af katastrofer, kriser eller sammenbrud. Derved kan naturen ikke udgøre noget ståsted for en evt. kritik af civilisatoriske skævheder. Forsåvidt vil det overhovedet været meningsløst at stille problemet på den led, da mennesket er identisk med sin historiske formning, og så er der ret beset heller ingen grund til at fortvivle.

Filosofihistorisk er Hegel den første, som foretager et generalopgør med naturretstænkningen og enhver umiddelbarhedstænkning, der rekurrerer til givne, umiddelbare forstillinger som absolutte sandheder uden at spørge om, hvad der subjektivt og objektivt kan have ledt tanken hen på disse forestillinger (f.eks. "naturen"). Begrebernes stivnede aprioriskhed skal opløses ved at tilspidse de immanente modsigelser, de skal drives til deres yderste, gøres flydende. Selv 'sandheden' gøres til genstand for en udfoldelseslogik, får proceskarakter. Således kan heller ikke naturen - hverken den indre eller ydre - udgør noget fixpunkt eller uantastelig kerne $i$ forhold til den historiske udfoldelseslogik.

Fra den marxske økonomikritik kender man imidlertid den problematiske side ved Hegels identitetslogik, hans identifikation af den borgerlige samfundsmæssighed med historien overhovedet, med proklamationen om det borgerlige samfund som værende det absolutte, fornuften, friheden. Her kan man ikke længere finde nogle modsigelser, hvis tilspidsning ville føre udover den bestående orden, der gives ikke længere nogle anticiperende momenter. Den hegelske logik anvendt som immanent rekonstruktionsprincip for kapitalens almene bevægelse ville $i$ en identitetslogisk udforming betyde, at kapitalen som ordnings- og udviklingslogik ville være suveræn og selvberoende i sin sætten-sig-selv, ikke bare i sin form, men også indholdsmœssigt; den ville så at sige være majestætisk hævet over det materielle substrat (som da ville være dets eget). Genstand og begreb er identisk. Marx nærede ikke den samme optimisme til modsigelsernes endelige forsoning og kunne heller ikke finde den postulerede harmoni i sin samtid. Gennem begrebets prøvelse - den kompromisløse tilspidsning - finder Marx, at kapitalen går svanger med en egen indre opløsningstendens, og at begrebet ikke er identisk med sagen. 
Vi kan her nøjes med at fastholde den fundamentale materialistiske pointe, at kapitallogikkens subsumtionsproces (hverken den formelle eller reelle) aldrig 100\% kan erobre eller 'sætte' sit eget matrielle grundlag, sit indhold eller stoflige substrat. Det grundlag, kapitalen livnærer sig af (indre og ydre natur) vil aldrig restløst gå op i kapitalrationalitetens formning af den; den vil yde modstand, udgør et træghedsmoment, besidde egensindighed, ha' sin egen logik.

Men er vi så med den "modne" Marx tilbage i den klassiske antropologifigur? Det er tesen $i$ det følgende, at N/K, der klart tænker i forlængelsen af de marxske bestemmelser, forsøger at finde et tredje "standpunkt" mellem de to yderpoler. Men dette "standpunkt" er ikke en positivbar platform, snarere et notorisk ping-pong spil, der med en armlængdes afstand til de overordnede, filosofiske programmer hellere forsøger at demonstrere sit forehavende "nede i materialet".

Men det enorme stofområde der aftegner sig i N/K's meget tværfaglige projekt, bevæger de sig i spændingsfeltet mellem enkelteksempler og generaliserede centralkategorier. På den ene side er de nødt til at operere med nye og provisoriske begreber, der skal bryde erkendelsesblokkeringer ved de gammelkendte termer. $\mathrm{P} \stackrel{\circ}{\text { den }}$ anden side kan de ikke unddrage sig generaliseringstendensen ved de oprettede kategorier, delvis fordi de spænder over et vidt felt, og delvis fordi de er forpligtet på en universaliserbar frigørelsesstrategi. Herigennem synes de at ryge ind i en traditionel effekt: gennem en højning af generaliseringsniveauet i begreberne bliver deres udsigelseskraft så omfattende, at de bliver intetssigende! I forsøget på at åbne op for nye perspektiver og utraditionelle forbindelseslinier er deres eneste imprægneringsmiddel mod 'intetsigelsen' det selvsamme middel, hvorved den opstod: nemlig stofrigdommen, eller mere korrekt; i den strøm af associationer og "aha"-oplevelser hos læseren, der følger i kølvandet på den stofnære gennemgang af konkrete eksempler og temaer - og hvis mangfoldighed øger chancen for at koble folk på associationsbanerne. Et eller andet sted vil teksten før eller senere træffe på nogle intellektuelle erfaringsbrokker hos hiin enkelte. Bogen spekulerer bevidst i dette subkutane område af latent intellektuel produktionsmateriale, og det er dens eneste 'garanti' mod den totale erkendelsesmæssige udvanding.

I denne korte opsats over $\mathrm{N} / \mathrm{K}^{\prime} \mathrm{s}$ bog er dét netop forbandelsen, at man afsnører sig fra den erfaringsgehalt, der motiverede og genererede de overordnede reflektioner, ligesom afsnøringen øger sandsynligheden for at koble eventuelle læsere af $i$ svinget, enten det nu er af uforståelighed eller kedsommelighed. Hvor $\mathrm{N} / \mathrm{K}$ kan udfolde deres synspunkter i øjenhøjde gennem et mangfoldigt materiale, der kan trække læseren med i en 'e- 
genproduktion' af tankefigurerne, så ligger der i dette stykke papir en konstant fare for at skære denne livsnerve over. Problemet kan kun provisorisk afhjælpes gennem nogle særlige udvalgte eksempler og referencer.

Vor læsning vil være "voldelig"; nemlig ved at forsøge at gennemføre nogle overordnede metareflektioner på teksten, samle brudstykker af metodiske overvejelser og organisere disse efter antropologi-snakken.

\section{"ARBEJDSKRAFTENS POLITISKE ØKONOMI"}

I "Kapitalens" 1. kapitel om varen, hvor begreberne om det abstrakte- og konkret-menneskelige arbejde etableres (med deraf følgende bestemmelser om værdi og brugsværdi), gør Marx opmærksom på, at der vil blive fokuseret på værdi-siden. Den anden side, som han en passant benævner 'varekundskaben', læren om de konkrete brugsværdier, deres materiale opbygning og funktion, lades ude af betragtning, eller mere korrekt; brugsværdibestemmelsen er kun med, forsåvidt den er bœrer af værdien. Denne udgrænsning bunder ikke kun $i$ en fremstillingsøkonomisk prioritering, men $i$ en principiel fremstillngslogisk nødvendighed; der er nemlig kun værdilogikken, der lader sig fremstille i en sammenhængende - omend modsætningsfyldt - og almen bevægelsesform. Men det betyder på den anden side ikke, at brugsværdien ingen betydning har for værdiformsanalysen, tværtimod er det denne dobbeltkarakter, der udgør spændingsfeltet hele analysen igennem. De lader sig ikke skille ad. Men fokus i 'Kapitalen' ligger på den ene pol

$\mathrm{N} / \mathrm{K}$ ønsker at foretage dette perspektivskifte i deres projekt med at skrive 'arbejdskraftens politiske $\phi k o n o m i '$ et forsøg på at se den kapitalistiske krisesammenhæng "nedenfra", fra brugsværdisidens standspunkt at skrive Kapitalen "baglæns" (hvor kapitlet om den oprindelige akkumulation må komme først). Modsat - men ikke i modsætning til Marx vil de beskrive subsumtions- og prægningsprocesserne fra de konkrete menneskelige arbejds- og livsevners side.

Men hermed ophører også analogien til 'kritikken af den politiske $\varnothing-$ konomi'. Der kan ikke være tale om to paralelle og ligeværdige historier eller 'videnskaber'. Det systematisk diskursive eller historie-kronologiske er fraværende, og fremstillingen synes at være en uendelig march på stedet. Organiseret omkring sammenføjningspunkter, brudflader, tyngdepunkter, gravitationsfelter bliver temaet konstant hægtet op på filigranagtig oprullede modsætningsformer, der heller ikke lader sproget uberørt. Det uhåndterlige viser sig bl.a. i deres vekslende brug af 'arbejdskraft' og 'arbejdsevne' som improvisoriske, "arbejdende begreber". 
Når N/K bruger termen arbejdsevne i stedet for ąrbejdskraft i visse sammenhænge, ønsker de at vise hen til et arbejdsbegreb, der ikke snævert er knyttet til det kapitalistiske lønarbejde, men er bredere både historisk og tematisk; det går længere tilbage i historien, og det indbefatter andre omgangsformer med naturen end den målrationelle og instrumentelle beherskelsesstrategi (mimetiske omgangsformer som f.eks. jordemoderkunsten, der er sluppet fri af den instrumentelle arbejdsprocs' voldsomhed og ligegyldighed overfor objektet. At bringe barnet i orden indeni maven kræver godt nok kraft og har et formål, men det foregår efter naturens egen rytmik).

Etymeologisk kan man også påvise, at evne-begrebet har en længere historie end kraft-begrebet, der opstår med det mekanistiske verdensbillede. Med oplysningsfilosofien bliver kraft- og energibegreberne også centralkategorier for samfundstænkningen, som forklaringselementer og betegnelser for de væsentligste samfundsmæssige og historiske fænomener. De karakteriserer den indsigt, at naturen lader sig forme af menneskelige indgreb. Et indgreb, der ikke er ad hoc-præget eller et randfænomen, men som gennem sin kvantitet og vedvarenhed rykker ind i centrum af den menneskelige subsistens og bevidsthed. Menneskelig fremskridt og lykke er betinget af en vedvarende produktivitetssøgning.

Kraft bliver her det modsatte af evne. Hvor de menneskelige arbejdsog livsevner er bundet til et artshistorisk grundlag, hvor individet er det væsentlige - nemlig som bærer af disse evner, så er kraftbegrebet indifferent overfor dette materielle grundlag. Arbejdskraften er en overindividuel størrelse, hvis historie ikke er bundet til bærerne, men til resultaterne (det døde arbejde). Arbejdsevnerne viser hen til den personlige biografi, til subjektivitet, mens arbejdskraften har afsnøret alle forbindelser til sine konstitutionsbetingelser.

Begrebet om arbejdskraften kan ikke erstatte begrebet om arbejdsevnerne eller vice versa. De er samtidige, og det er dialektikken mellem dem, som interesserer $\mathrm{N} / \mathrm{K}$.

Den omfattende masse af menneskelige evner og kompetencer, der har nedfældet sig gennem artshistorien i utallige brud, fortætninger og forskydninger, og som $i$ høj grad formidles over et "førbevidst" socialisationsagentur $i$ individualhistorien, forbliver skjult eller lever sit liv "under huden" (subkutant), eller også eksisterer de som blotte selvfølgeligheder, det jo er lige så vanskeligt at opdage! De lader sig ikke begribe "rent", som biologiske konstanter, men kan kun spores negativt, som mangel eller i deres kriseramthed, når de støder sammen med kapitalens eroderende formsætning. Således er begge poler lige vigtige for 
N/K's evolutionsteori, og derfor kan denne evolutionshistorie kun beskrives punktuelt og usammenhængende; i det øjeblik det materielle grundlag krakelerer og "laver koks i maskineriet".

Kriser, sammenbrud, katastrofer, kollaps, erosioner, neuroser osv. er de knudepunkter, der først muliggør opdagelsen af denne arbejds- og livsevnernes evolutionshistorie. I stedet for en "oprindelighedstænkning" drejer det sig om at fokucere på "midtpunktet" eller "tyngdepunktet", nemlig den kapitalistiske adskillelsesproces med dens gravitative og eroderende effekter på arbejdsevnerne.

"Begyndelsen, dvs. den gennemgribende adskillelse, ligger ikke i uroprindelsen, men derimod centralt ... Denne betegnelse for det historiske drejepunkt er vilkårlig: det, som den oprindelige akkumulation og dens opsplitning bevirker, kan være noget højst nutidigt, sågar fremtidigt. Ved genfortællingen af det, vi med et ikke nærmere analyserbart begreb historieforl $\phi b$ har tildækket, støder vi hurtigt på, at disse processer ikke udviser noget lineært forløb. De har ingen tvingende grund til kontigens, de enkelte ender kan berøre hinanden, eller også kan de ikke".

$$
\text { G \& E s. } 35
$$

"Adskillelsen" som systematisk forklaringskategori for opståelsesprocessen (af arbejdsevnerne) postulerer ud af resultaterne en opståelsesgrund; denne igen som resultat. Vender man derimod kategorien derhen, at den undersøger kodningen af processen - og ikke resultatet -, så opererer begrebet anderledes; man kan tydeliggøre det ved tidsstrukturen: det er ikke længere begyndelsespunkt eller slutpunkt for bevægelsen og måleforhold for dens forskellige hastigheder, men derimod organiserende centra, fra hvilke specifikke bestemmelser, i kraft af de dertilhørende sammensatheder (koncentration, masse), udgår, i løbet af den historiske udvikling. Denne organiserende kerne bestemmer ganske vist gravitationen, hvori de enkelte arbejdsevner kan adskilles, sætte sig sammen, transformeres; i det samme grundforhold kan de også blive tilintetgjort, tilbagebøjet. Vi antager ikke, at det nødvendigvis er et centrum, $i$ hvilket en oprindelig organisation af de styrende processer i udviklingen finder sammen efter mønster af et krystalgitter; der kan også opstå flere sådanne polarisationer, så, at der består (en) flerpolet dialektik i disse forhold".

G \& E s. 544, note 4

Adskillelsesbegrebet er for $\mathrm{N} / \mathrm{K}$ lige så meget en systematisk kategori som en historisk, der er mere at forstå som et gravitationsfelt end som 
et fixpunkt i historien. Deres "evolutionsteori" er hvẹrken kronologisk eller systematisk, og kan aldrig være det.

I forlængelse af Marx' bestemmelse om den "såkaldte oprindelige akkumulation" fortager N/K derved en principiel udvidelse af kategorien til at være et pregnant socialisationsbegreb. Grundlæggende karakteriserer begrebet de adskiltelsesprocesser, der finder sted mellem de umiddelbare producenter og deres produktionsredskaber. Historisk har de primært været knyttet til fordrivelsen fra jord og grund, hvorved konstitueringen af den frie arbejdskraft først kunne finde sted, og den udfoldede kapitalakkumulation etableres. Hvor Marx f.o.f. benytter termen i dette historiske eller sociologiske perspektiv, så ønsker N/K at forfølge adskillelsesprocessernes afsmitningseffekter og spredning. i alle facetter. Den oprindelige akkumulation lader sig ikke forstå som "einmalig", som en proces, der har udspillet sig ved kapitalens historiske fødsel og sidenhed været principielt overflødig. Ligesom kapitalen må reproduceres på ny og på et stadig højere niveau, så må også den oprindelige akkumulation og dens adskillelsesprocesser gentages til stadighed; den er permanent. Den må gentages for hver ny generation af arbejdskraftbærere og er kardinalbetingelse for kapitalens fortsatte beståen, følgelig et centralt socialisationsfænomen.

Den overgribende samfundsmæssiggørelse ernærer sig ikke blot af et passiyt dødt materiale, men lige så meget af levende arbejdsevner og dispositioner, et historieprodukt, som det selv ikke kan frembringe. Kapitalen forudsætter, som et historisk udgangspunkt og som et stadigt tilstedeværende materielt grundlag, at der forefindes et arsenal af arbejdsevner, egenskaber, kompetencer, viljesstrukturer, mentale dispositioner, emotionelle strukturer, samfundsmæssige institutioner, kulturelle former, sociale normer osv.

Dette er elementer, som selv har en egen-historie, dvs. ikke 'oprindeligheder' i naturalistisk forstand, men disse historier er ikke reducerbare til den kapitalistiske. Det betyder, at kapitalen lever på et grundlag, som den både reducerer, diffenrentierer, destruerer og udfolder, dvs. en modsætningsfyldt bevægelse af fremskridt og regression. (I den grad den fremskredne kapitalakkumulation har som effekt, at disse ikkekapitalistiske forudsætninger destrueres - og kapitalen kan ikke selv restituere dem - da taler N/K om en erosionskrise; en tendens, der ikke lader sig påvise eller afkræfte på et alment plan andet end som mulighed, men som må udfoldes gennem en konkret og historisk specifik analyse).

Vigtigt i denne sammenhæng er det imidlertid, at man med det stoflige eller materielle grundlag ikke forstår en form for naturalistiske 'oprin- 
deligheder' eller fysiologisk/fysisk invariable størrelser, der ingen historie har. Godt nok kan dette materiale synes passivt og trægt, men ikke trægere, end at det har sine egne udviklingslogikker, materielle specificiteter eller tidsmæssige rytmer, sine egne historier. Og disse historier er ikke nogle der udvikles "an sich", uafhængigt af den samfundsmæssighed, som de indlejres i. Det lader sig ikke gøre at beskrive forholdet ud fra en stiv form/indhold-dualisme. Kun i kollisionerne mellem det stoflige grundlag og den historiske udviklingsdynamik (de retningsbestemmende determinationsstrukturer, in casu det kapitalistiske merværdi imperativ) kan N/K udlæse den egensindige "naturs" tilstedeværelse. Som mere eller mindre "vellykkede" sammenstød vil man kunne fastslå, at der findes nogle kritiske eller negative grænser for kapitalens omstrukturerings- og. prægningsforsøg; eller $\mathrm{i}$ det mindste kan man som konsekvens konstatere kriser, sammenbrud, erosioner, kollaps, neuroser osv. Sådanne grænser, der ikke lader sig generalisere udover det enkelte fænomen, lader sig derfor heller ikke bestemme som en positivt eksisterende antropologisk kerne. I vor læsning af N/K er det således vigtigt, at deres begreber om 'indre natur', 'emancipatorisk minimum', 'blok af proletarisk erfaring', 'selvregulering' osv. netop ikke forstås som sociologiske, empirifiserbare eller operationaliserbare størrelser, men som socialisationskritiske grænsebegreber. Når N/K f.eks. i "Offentlighed og erfaring" forsvarer den ellers så tvivlsomme distinktion mellem "sande" og "falske" behov, så er det for at holde muligheden åben for et (omend skiftende) kritikståsted overfor relativistiske positioner, der hævder, at alle behov er lige gode, og som derigennem må opgive enhver tale om fordrejning, pervertering, afstumpning og fremmedgørelse.

"Kategorien sande behov m̊ under de bestående forhold have noget changerende, uhåndterligt over sig, fordi den kun vil kunne få afprøvet sin sandhedsgehalt i udfoldet form: alligevel eksisterer de som noget, der udfolder sig. Fordi de findes, har følgende sætning en indholdningsmæssig betydning: spørgsmål om sande behov indeholder en konkret anvisning på at afværge falske behov."

"Offentlighet og erfaring" GMT 1974, s. 84

Udsagnet, der forbliver indholdsmæssigt ubestemt og ikke forpligter sig på dette eller hint 'sande behov', skal først og fremmest forstås som en kritisk memento. Det drejer sig altså ikke om et sæt af naturlige og oprindelige behov, evner, psykiske dispositioner etc., som man kan hive frem og slå i bordet med overfor diverse produkter fra den kapitalistiske civilisatorik. 
Fra "Offentlighed og erfaring" var man udgået fra begrebet 'blok af proletarisk, erfaring', som skulle angive de udgrænsede erfaringsområder, der ikke lod sig erkende gennem den borgerlige offentligheds perspektiver, materialer og mekanismer, eller de lod sig kun erkende som substansløs vedhæng. Nu kunne man imidlertid heller ikke begribe den borgerlige offentlighed ud fra sig selv, den måtte netop profilleres gennem sine udgrænsningsmekanismer. Denne standpunktforflytning gav derigennem et nyt perspektiv på den borgerlige offentlighed, men ikke noget mere substantielt til begrebet 'proletarisk offentlighed'. Her gives der fortsat kun

"snitpunkter, perspektiver, henvisninger til deres nødvendige bevægelseslove: åbne spørgsmål. Spørger vi videre, så vil blikket, der retter sig stift mod den proletariske offentligheds substandspørgsmål, intet analytisk frembringe. Det er ingen nødvendighed med en perspektivveksling: hvad er det, som nødvendigvis selv udgrænser det direkte spørgsmål eller den proletariske offentlighed?

Denne proletariske offentlighed gives som behov og som ikke-offentlig råstof, der er skjult i historien for al hidtidig produktion.

G \& E s. 88

Eet af elementerne ved dette "ikke-offentlige råstof" - som fundamentalt adskiller den fra kapitallogikkens økonomi - er dets karakter af en 'balanceфkonomi'. Hvor den rationelle energi-økonomiske betragtning bygger på en antagelse om, at energi der forbruges i ét delsystem, har som konsekvens, at der kan overføres mindre energi til et andet, så forholder det sig fundamentalt anderledes med den menneskelige arbejdskraft. Højt energiomløb på eet område kan udmærket godt medføre - eller endog være en betingelse for - en større ydelse på andre områder. 'Omvejsproduktion', fantasivirksomhed, protestarbejde, tydningsarbejde, skaben tillid, kulturel dannelse, dagsdrømmeri osv. er konstant tilstede som nødvendige processuelle momenter ved enhver arbejdsopgave, også den slags man finder under den maskinelle storindustris samlebåndsarbejde.

Begrebet om balanceøkonomi skal ikke forstås på den. måde, at der findes én balance, et biologisk givet optimalpunkt for afvejning af alle de forskellige arbejds- og livsevner. Der er i stedet tale om forskellige balanceøkonomier f.eks. børn, voksne, gamle, kvinder, mænd, arbejderklasse, intellektuelle osv., dvs. at de også forandrer sig historisk.

Betydningen af denne balanceøkonomi for arbejdsevnerne er især blevet et akut problem efter den gennemgribende taylorisering af det levende arbejde, hvor man hurtigt stødte på grænser for opsplitning og rationalisering af arbejdsoperationerne; grænser, der har ytret sig håndfast og kompromisløst, f.eks. i form af faldende produktivitet, højnet ulykkes- 
frekvens, stort gennemtræk af arbejdere, faldende koncentraktionsevne osv.

Blot et eksempel (fra Marx) til belysning af den fundamentale horisont-(eller interesse-)forskydning, der finder sted mellem de to "økonomier"; nemlig forskellen på pengebesidderen og arbejdskraftbesidderen. Den sidstnævntes besiddelse er en ren fiktion, fordi sælgeren af denne vare ingenlunde besidder den i salgsøjeblikket. Besiddelsen af varen arbejdskraft må permanent oparbejdes i arbejdsprocessen. Denne er nemlig dobbelt; delsvis er det en produktion af varer, og delsvis er det en produktion af arbejdsdisposition. Hvor den ivrige pengebesidder kun forefinder eet produkt, foreligger der for den mere modvillige arbejdskraftbesidder to. Den ene produkt opstår i bytteforholdet mellem lønarbejde og kapital, det andet består $i$ et bytte mellem indre forhold i arbejdskraften selv, dvs. i "et produktionsforhold mellem arbejdskraften som vare og som livsvœsen." Modsat kapitallogikken er arbejdskraftens synsvinkel sådan, at det færdige arbejdsprodukt (den fremstillede vare) er et biproduktion, mens processen i arbejdskraften selv er hovedprodukt, et stykke virkeligt liv.

Perspektivforskydningen består i, at man i stedet for modsætningen mellem kapital og lønarbejde fokucerer på modsætningen mellem individ og artshistorie. Dette er den centrale modsætning i arbejdskraftens politiske økonomi, og den sprænger permanent den politiske økonomis begreb; for pengebesidderen er byttet besørget i og med det færdige produkt, for besidderen af varen arbejdskraft er det først nu dobbeltarbejdet begynder.

Produktionen af arbejdsdisposition, der ikke blot inkluderer indlæring og vedligeholdelse af faglige-tekniske færdigheder, men også "omvejsproduktion", fantasivirksomhed, protestarbejde osv., falder i al borgerlig arbejds-forskning systematik udenfor; for den kapitalistiske rationaliseringsekspert drejer det sig om "splidtid". For arbejdskraften er det imidlertid en indre lov, balanceøkonomiens fundamentale mekanisme: uden dette tillægsarbejde kunne der overhovedet ikke finde nogen arbejdsproces sted. Hvis man forsøgte at lukke disse "huller" ville resultatet blive sammenbrud, krise, opløsning, kollaps. Denne selvregulerende balanceøkonomi bemærkes da også kun i sine patologiske udslag; indenfor de eksisterende enkeltvidenskaber, der beskæftiger sig med feltet, forefindes der kun som forstyrrelser og dukker kun sporadisk op i synsfeltet. Fra arbejdskraftens synsvinkel er det imidlertid en sammenhcengede proces, dvs. et behov for association, fællesvæsen, solidaritet, gensidig anerkendelse.

Den af kapitalen satte adskillelse (arbejdsdeling, konkurrence, parcellering, robinsonader) medfører en kontinuerlig knægtelse af denne sam- 
menhængskraft (med dertil hørende realitetstab som følge). Den reaktionsform, som opstår på denne knægtelse, kalder N/K for egensindigheden. Det er en evne, som kun har magt over lidt; den har ingen almenhed og ingen magt over samfundsmæssige totalitet. Det er en partikulær frihed indenfor knægtelsens område. Egensindigheden er en konsekvens af adskillelsen og tillige en refleksagtig reaktion mod den. Men denne modmagt er defensiv og konserverende, den peger ikke ud over knægtelsen. Den er ingen utopi eller idealtilstand, men bastant realitet; den er opstået og genopstår uafladeligt af bitter nød. Den er ikke blot en passiv akcept af status quo, men selv en aktiv komponent i reproduktionen af denne. Egensindigheden er dobbeltsporet og følgelig intet entydigt emancipationspotentiale, selv om den udgør det nødvendige næringsgrundlag.

Modsætningen mellem det levende og det $d \phi d e$ arbejde, grundforholdet i den kapitalistiske akkumulationsproces, fremviser denne pregnante assymmetri. Det levende arbejde slår sig ned i produktionen og forsvinder deri; det går over i dødt arbejde (forsåvidt som det genstandsmæssiggør sig). Det levende arbejde står således overfor det samlede resultat af sin egen forhistorie (det døde arbejde) som overfor det uhyrlige og fjendtlig overmagt, idet denne har organiseret sig efter en anden tidsgestalt end de artshistoriske (der skjuler sig i det individuelle livsforløbs rytmer). Dette medfører så en grundlæggende erfaringsblokering for det levende arbejde: vekselvirkningsforholdet mellem det levende og døde arbejde kan, p. gr.a. disses foreskellige produktionstider, ikke erfares på et individuelt niveau. (Til dette kræves der en kollektiv erfaringssammenhæng, en proletarisk offentlighed.) Det døde arbejde, der fremtræder som en fjendtlig magt, er imidlertid ikke mere overmægtig end, at det på liv og død er prisgivet det levende arbejde. Kun det levende arbejde kan bringe det døde i tale, hvis de to poler ikke længere står i rapport til hinanden, så vil det døde arbejde falde tilbage til død natur, til en meningsløs ansamling af materiale og skrald. Kun det levende arbejde er intentionalt. Revolutionsteoretisk ligger det levende arbejdes brod i det forhold, at de menneskelige arbejds- og livsevners kompleksitet ikke lader sig indskrive $i$ ejendomsformerne. Dets kompetencer er der ingen som har råderet over, kun dets resultater. De subkutane processer lader sig ikke (andet end rent punktuelt) indfange institutionelt. Men deri ligger lige så meget deres svaghed, de kan ikke genstandsmæssiggøre sig (fra blot mulighed til 'virkeliggørelse') andet end gennem det kapitalistisk organiserede lønarbejde. Og i den grad, de realiseres 'udenfor', sker det i partikulære nicher, der producerer afstødningsmekanismer. Arbejdskraftens unddragen-sig ejendomsbegrebet - dens egensindighed - er tillige dét, der 'muliggør' en emancipatorisk organisering. 


\section{MØDE MED BIOLOGIEN}

Med de menneskelige arbejds- og livsevner forholder det sig som med isbjerget; ni tiendedele ligger under overfladen. At erfaringsdannelse ikke kun er en kognitivt bevidst proces har siden Freud ikke været nogen nyhed. Idag finder man den samme pointe hos en efterhånden omfattende terapibevægelse, der gør gældende - omend tit i en metafysisk terminologi - at væsentlige erfaringsdannelser og -bearbejdelser finder sted i kroppen og ikke blot som kognitivt bevidste overvejelser eller registreringer i hovedet. Endvidere har lingvistikken hævdet, at end ikke sproget - bevidsthedens eget medium - er at forstå som en bevidst struktur, der helt og aldeles er transparent for det enkelte individ. Som en overindividuel, og i høj grad 'subkutant' struktur, indlæres den ad andre kanaler end logikken, ènd er så at sige et "historisk apriori".

Således tematiserer også N/K det felt, som de provosorisk kalder arbejdskraftens politiske økonomi. Store dele af de menneskelige evner, kompetencer og anlæg er usynlige, de "sidder i rygmarven", "ligger i fingerspidserne" eller ligger i fornemmelsen, intuitionen osv. Menneskebarnets uendelige komplekse og langvarige erhvervelse af de fornødne motoriske, emotionelle og intellektuelle strukturer fortæller såvel noget om, hvor omfattende denne proces er, som tillige hvor selvfølgelig den er! Og det gælder ikke kun barnets erfaringsdannelse, også den voksnes mere målbevidste lære- og erhvervelses-processer indgår i dette store usynlige kontinent.

I forsøget på at skrive en "evolutionsteori for de menneskelige arbejdsevner" kommer man vanskeligt udenom de biologiske videnskaber, og det har da heller ikke N/K nogen anfægtelser over. Hvad man i stedet skal være opmærksom på er de mere eller mindre velovervejede ideologemer ellermetateoretiske konstruktioner, der tit følger med, som f.eks. naturalismen. Når N/K konstant slynger om sig med kategorier og eksempelmateriale fra biologien ('selvregulering', 'kredsløb', 'balancearbejde' osv.) er det selvfølgelige straks nærliggende at stille spørgsmålet, om de vil reducere genuint historiske forhold til "mere fundamentale" biologiske forhold. Går man ombord i teksten, opdager man imidlertid hurtigt, at de ikke er på udkik efter biologiske konstanter (som tit ender i en opremsning af banale eksistensbetingelser: behov for føde, udskillelse af affaldsprodukter fra stofskiftet, behov for forplantning osv.). Sådanne banaliteter forbliver netop ubestemte $i$ deres form: "Sult er sult, men sult, der tilfredsstilles af kogt kød, der spises med kniv og gaffel, er en anden sult end den, der sluger råt kød ved hjælp af hånd, negl og tand" (Marx: Grundrisse s. 13). Og det er netop de historiske former og deres adskillelses- og differentieringsprocesser, som interesserer $\mathrm{N} / \mathrm{K}$. 
Hvad er det så, de ønsker at beskrive ved selvreguleringskategorien? Tidligere har Negt anvendt selvregulering som et centralt pædagogisk ledemotiv ved Glocksee-skolen:

"Selvregulering kan ikke forstås som blot politisk eller pædagogisk postulat, som udefra tilbydes skolen eller børnene, omtrent med kravet: 'Reguler jer selv!' eller 'I skal gøre, hvad I vil, og hvad der netop falder jer ind!' ... Ganske vist kan børnene gøre og lade som de vil, men hvad de faktisk $g \phi r$, er som regel alt andet end vilkarligt og tilfaldigt, ... Den samfundsmæssige standardisering af adfærds- og tankemåder, som stammer fra den kapitalistiske vareproduktion, skaber et begrænset og overskueligt antal problemer $i$ en skole. Grundlæggende vil det først ændre sig, når menneskene bliver virkelig frie og autonome subjekter ... Glocksee-skolen kan ... ikke skabe en principel ny realitet. Den forarbejder, strukturerer, udvikler den forhåndenværende realitet, ganske vist på en måde, hvorved der dermed også lukkes op for nye erfaringsdimensioner ... Det gælder fremfor alt med henblik på udviklingen af kollektive, samfundsmcssige fwrdigheder. ... den betegner en proces, som, idet den nedbryder blokering af adfærd og bevidsthed, samtidig realiserer sit målindhold: udvidelsen af barnets erfaringsevne og dannelsen af autonomi."

Kontext nr. 35, Modtryk 1978, s. 74

Grundlæggende ved dette læreprincip er antagelsen om, at børns adfærd og bevidsthed ingenlunde er et uregerligt kaos, som det er op til pædagogikken at organisere. Under den skolemæssige afretning og udgrænset fra denne ligger et stort erfaringsområde, der for det første overhovedet muliggør, at noget læres, og som for det andet har sin egen bevægelses'logik' (eller logikker). Vel vidende om skoleforsøgets partielle placering i børnenes samfundsmæsige tilværelse var intention af lade de udgrcensede erfaringsområder 'kommer til orde', idet man havde en forventning om, at børnene herigennem var bedre rustet til en (kritisk) bearbejdning af den omkringliggende og fremtidige realitet. Har man på den ene side afgrænset sig mod det gamle pædagogiske diktum om, at opdragelsen må være en overvindelse af 'naturlige tilbøjeligheder' ved hjælp af ydre pres, så nærer man på den anden side heller ikke illusioner om, at opdragelsen er en harmonisk bevægelse, der kommer indenfra så at sige af sig selv. Retningsbestemmelsen af denne socialisering er netop betinget af kollektiviteten.

I G \& E synes det som om, man har med et endnu mere generaliseret selvregulerings-begreb at gøre; et formelt overbegreb, der skal favne over en bred vifte af fænomener. Denne tværvidenskabelige samlekategori 
skal i al korthed karakterisere de autonome natur- eller materialebundne processer, de originære organers kredsløbsagtige egetliv, fra de mindste biologiske celler til samfundsmæssige interaktionsformer nedfældet gennem utallige generationer.

Begreberne om selvregulering og kredsløb henter $\mathrm{N} / \mathrm{K}$ ikke fra kybernetikken, som for dem at se repræsenterer præcis det modsatte. Den sociale kybernetik indebærer en reduktion af mangfoldigheden med henblik på overskuelighed og planlægningsmulighed. Men reduktion af kompleksiteten betyder også en fortrængning og abstraktion fra det vitale materielle grundlag.

Selvregulering betyder for $\mathrm{N} / \mathrm{K}$ snarere en regulerings- og styringsform, som langt fra at reducere mangfoldigheden hellere vil lade den komme til sin ret. Men denne mangfoldighed lader sig ingenlunde bringe på én (harmonisk) formel ud fra et i naturen nedlagt koherens-eller korrespondensprincip; at der i naturen selv skulle forefindes en sammenhængskraft eller en immanent harmoniseringsdrift, der vil bringe de mange egenlogiciteter på mindste fælles multiplum, blot man får afstrejfet den repressive samfundsmæssighed. I et emancipatorisk perspektiv - allermindst - kan man forlade sig på "Naturens" selvreguleringskraft, at den af sig selv skulle kunne (gen)etablere en frihedens orden.

Ganske vist forstås selvregulering som en naturkvalitet, men da det i historien - og emfatisk forstand under den kapitalistisk organiserede samfundsmæssighed - altid drejer sig om sammensatte processer mellem antagonistiske selvreguleringssystemer (i deres historiske formede specificitet), så vil de enkelte kredsløbs virkeliggørelse præcis ikke være noget selvstændigt eller noget selvberoende og selvgenereret (Kein Selbstlauf), noget der udspringer fra det enkelte kredsløb selv. Kun negativt kan man fastslå, at de emancipatoriske processer ikke kan finde sted uden hensyntagen til de mange selvreguleringssystemer $i$ den menneskelige artshistorie. Ligesom den repressive historiske forming, må også omvæltningen af denne foregå mellem indgreb (Eingriffe) "udefra", fra det historiske rum. Overladt til sig selv kan selvreguleringssystemernes addition føre $i$ en hvilken som helst retning (og $i$ det hele taget er det kun som tankeeksperiment, at de kan overlades til sig selv). For det samfundsmæssige menneske gives der ikke een natur (Naturen). Der gives ligeså mange distinktioner (adskillelser) mellem "naturligt" og "konstrueret", som der findes menneskefremstillede subjekt-objekt forhold. Hvert af disse forhold ved de menneskelige arbejds- og livsevner har en andel konstruktion og en andel selvregulering, som ikke lader sig adskille andet end analytisk. Men det betyder omvendt, at også de historiske former har indbygget momenter af selvregulering. Det synes at være disse kredsløbssystemers in- 
dre træghed - egensindigheder - som den moderne og højst accelerede kapitalakkumulation støder sammen med, hvorved der aftegner sig nogle nye krisefænomener .

Det forhold, at man ikke kan etablere en positiv antropologi, gør det ikke overflødigt at operere med selvreguleringssystemer som elementardele $i$ en teoretisk beskrivelse. Der balanceres hele tiden mellem to figurer, som synes at være kontradiktoriske; på den ene side selvregulering, der er at forstå som en lukkethed, et selvtilstrækkelig kredsløb eller monade, som N/K også kalder det med reference til Leibniz. På den anden side har man konstruktion, hvis karakteristikon er ảbenhed, relationalitet og fremdrift eller vindue, som de kalder monadens oppositionsbegreb. På politisk formel kan det samme spændingsfelt beskrives som forholdet mellem organisation og spontanitet.

De fastholder modsætningen, men ikke som en dualistisk modstilling, hvor man tager standpunkt for den ene pol mod den anden, eller hvor man forsøger at trække gyldighedsgrænserne for de respektive områder. For N/K er det ikke et logisk, men et historisk problem; det er lige præcis den labile konfrontantionslinie mellem den 1. og 2. natur, der er temaet. De originære organers selvreguleringsprocesser er de nødvendige kulisser, der skal synliggøre den historiske scene, som kapitalen udfolder sit skuespil på. Som kulisse og baggrundslandskab tjener de en erkendelsesfunktion ved kontrast- og silhouetvirkninger, ikke som et positivbart antropologisk ståsted.

\section{UDFLUGT: OPGøRET MED HISTORIEFILOSOFIEN}

Fra jødedommens forestilling om menneskets adskillelse fra paradiset til Hegels triade: oprindelig enhed - adskillelse - forsoning har adskillelseskategorien haft en central placering i historiefilosofiske spekulationer. Med ståsted i den marxske økonomikritik gør N/K opmærksom på, at historiefilosofiens begreb-om gentilegnelse af den tabte enhed ikke længere duer som emancipationskategori, fordi radikaliteten og omfanget i de kapitalistiske adskillelsesprocesser $i$ mellemtiden har sat kvalitativt nye historiske former og organiseringer af de menneskelige arbejds- og livsevner, der ikke lader sig tilbagerulle, i alle fald ikkei dens helhed. En emancipation, der vil være på højde med sin tid, kan ikke nostalgisk orientere sig efter "den tabte tid", men kan kun have sine referencer i den aktuelle historie, med dens altid tilstedeværende muligheder og anticiperende tendenser.

Den filosofiske kategori 'gentilegnelse' er en refleksbestemmelse af 'afhændelsen' og har sin grund et andet sted. Civilisatorikkens irrever- 
sible og uigenkaldelige fremadskriden kræver noget 'Tredje'. Op imod 'gentilegnelsen' stiller $\mathrm{N} / \mathrm{K}$ begrebet 'virkeliggфrelse', at der må gribes fat $i$ de reelt forfundne tendenser (der peger ud over de borgerlige samkvemsformer), som er slynget ud og konstitueret gennem adskillelsesenergiernes frigøren og nyetablering.

N/K opløser altså historiefilosofien, men fastholder adskillelseskategorien, dvs. uden at forpligte sig på dennes oprindelige programmatik: projektionen af en universel og logocentrisk bevægelsesform i historien og den filosofiske antagelse om et skjult telos i historien. Udsigelseskraften i adskillelsesbegrebet lader sig ikke dividere op i historiefilosofiens brug af den.

Historiefilosofien ophæves derigennem, at 'adskillelseskategorien' bliver flerdimensional både i tid og rum. Rummet er ikke længere homogent og tidsaksen ikke længere lineær, sådan som den universaliserende logocentrisme. $\mathrm{N} / \mathrm{K}$ markerer dette brud ved bl.a. at operere med 3 "historier": artshistorien, individualhistorien og så historien (som sammenføjningsstedet for de forskellige historiers sammenstød med kapitalens subsumtionslogik). Hver historie har sin tidsduktus, sine bevægelseslove osv. og den konkrete historie må således forstås som den kontinuerlige konfrontation mellem disse diskontinuerlige historier. Sammenf申jningspunkterne og brudfladerne er nok engang de centrale orienteringspunkter i projektet.

Usamtidigheden mellem disse forskellige historier skal ikke forstås hierarkiserende; der er ikke tale om noget historisk skema, som man kan måle efter. I forhold til den tyske historie gør N/K opmærksom på, at den tidsgestalt, som den oprindelige akkumulation her har, ikke kan begribes som en målbar afgivelse i forhold til den klassiske engelske udvikling. De sædvanlige talemåder om forsinkelse, efterslæb, tilbageståenhed osv. er konciperet efter en forestilling om en klart definerbar række af stadier, epoker, formationer og overgange. Når man således dukker ned for at finde de forskellige processer $i$ de forskellige områder, klasser, produktionsformer, traditioner osv., så er den tidsgestalt ikke at forstå som forskydninger på den selvsamme tidsakse, men som en anden kronologi, der omfatter en egen omfattende og samlet tysk historie:

"Forhastetheden (Verfrühtheit) og umodenheden ved en samfundsmæssig kamp eller forsinkelsen (Verspätung) i et samfund eksisterer kun som et falsk målesystem og ikke autentisk. For de tyske forhold antager vi i intet tilfælde en forsinkelse, men derimod i ethvert tilfælde, hvor der bliver talt om umodenhed eller forsinkelse, en genuin udvikling, som netop ikke lader sig tyde gennem en sammenligning med forholdene $i$ andre 
vestlige lande. Det er præcis anvendelsen af disse begreber, der arbejder med fremmede tidsmålestokke, som har tildækket de autochtone tidsmålestokke, med hvilke Tyskland skulle bearbejdes, og det har ført til, at fortætningen af konstellationer, der enkelte steder overhovedet ikke har nogen tydelig og udpræget udviklingsretning, men som ganske vist har en specifik situationslogik, er blevet overset. Det synes for os netop at være problemet ved den tyske historie, at udviklingsretningerne støder på hinanden, bøjer sig og bliver fordrejet eller afbrydes, således at man ud af denne helhed af processer, der løber ind-imellem-hinanden, kun vanskeligt kan lave en klar målbestemmelse, der er orienteret efter udviklingslinien $i$ et andet land".

G \& E s. 568

\section{ARVEN FRA ADORNOS NEGATIVE DIALEKTIK}

Når selvregulering ikke skal forstås hverken som rationalisering eller som naturalisering, når den logiske struktur ikke hentes hverken fra kybernetikken, eller biologien, så synes begrebet desto mere at stamme fra en fœnomenologisk tæenkning. Strukturen er hverken brudløst liniær eller cyklisk selv-repetetiv. Selvregulering forstås som udviklingsforløb, der forholder sig til sig selv. Processerne skrider fremad, men reproducerer tillige sine egne udgangsbetingelser, der hele tiden er til stede som tyngdepunkter.

Hegels erfaringsdialektik fra 'Phänomenologie des Geistes' angiver filosofihistorisk denne grundfigur, hvor selvreflektiviteten er selve drivremmen i den fremtrædende videns kommen til bevidsthed om sig selv på et stadig højere niveau, dvs. hvor den gennemlever en række brudflader mellem modsigelsesfyldte bevidsthedsformer. Til forskel fra Hegel er den erfaringsdialektik, som er på spil hos $\mathrm{N} / \mathrm{K}$, hverken systematisk diskursiv eller historisk målrettet (teleologisk rettet mod den absolutte ånd/verdensånden/fornuften"friheden/kommunismen). Ej heller forstås den som en udelukkende kognitiv bevidst eller snæver intellektuel proces, som brudflader mellem modsigelsesfyldte bevidsthedsformer. For $\mathrm{N} / \mathrm{K}$ er det netop en væsentlig pointe, at store strækninger af erfaringsakkumulation og -ombrydning foregå subkutant; deres tale om menneskelige arbejds- og livsevner angiver klart dette bredere sigte. Men hvori består da reflektivitetsmomentet, når de elementer, der er på tale, ligger indenfor det kognitivt bevidstes sfære, men lige så meget kan være "ubevidst", "ligger i rygraden" eller "i fingerspidserne" (Behutsamkeit, Sich-mühe-geben, Kraftund Peingriffe, Sich-trennen-können, Nach-hause-kommen, Fingerspitzgefühl, Trennschärfe osv. osv.)? Hvad er reflektivitet? 
Med en omskrivning af N/K's eget spørgsmål: Hvad er virkelig? kan man med en analog figur inddrage Freud. Freuds adskillelse mellem realitetsprincip og lystprincip, mellem det bevidste og det ubevidste er paradoksal. Fordi realiteten netop ikke er det hele, men har noget udenfor sig selv, der stemples af den som 'uvirkeligt'. Paradokset består imidlertid i, at det 'uvirkelige' (det ubevidste), dette ikke-empiriske kaos, virker ind på og strukturerer den virkelighed, som den angiveligt ikke er en del af. Det ubevidste er ingen pseudo-realitet eller blot repræsentant for noget mere virkeligt. Drømmmearbejdet er ikke en repræsentant for en reel ønskeopfyldelse, men er selve ønskeopfyldelsen. Der er indstiftet en ny og anden realitet, en psykisk realitet. På analog vis gælder det for reflektiviteten, at der udenfor enkeltindividernes bevidste kognition gives et moment af reflektivitet (akkumulation, bearbejdelse, brud etc.) i selve det historiske samfundsmæssige eller kollektivite medium, indskrevet på de individuelle- og samfundsmæssige legemer.

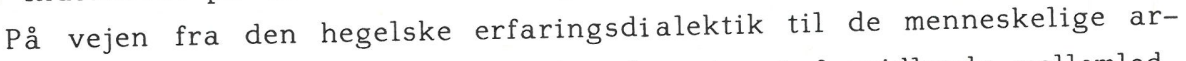
bejdsevners evolutionshistorie skjuler der sig. et formidlende mellemled, nemlig Adorno's 'negative dialektik'. Opgøret med Hegels diskursive systematik og historiefilosofiske teleologi ligger klart i forlængelsen af Frankfurterskolens positioner, ligesom den prismatiske skrivestil i mangt og meget ligner Adornos. I det mere konkrete forsøg på at opridse de subkutane erfaringsområder synes $\mathrm{N} / \mathrm{K}$ imidlertid at gå ud over Adornos temakreds.

Som angivet lader 'arbejdskraftens politiske økonomi' sig ikke fange $i$ en systematisk og logisk fremstillingsstruktur sådan, som det gælder for dens modpol; kapitalen. N/K's allergi mod overbegreber og almene kategorier er ligesom hos Adorno motiveret ud fra ønsket om at opspore det ikke-identiske; det, der netop falder udenfor almenbegreberne, ligesom det falder udenfor og udgrænses af den kapitallogiske rationalitet (den instrumentelle fornuft). Dette til forskel fra Hegel, som ikke etablerede nogen uoverstigelig kløft mellem det enkelte og det almene. For det første hævdede Hegel, at man kunne nå frem til det enkelte via almenbegrebet 'det særegne', og for det andet var der for Hegel at se ingen anden mulighed! Denne begrebs- og almenhedshypostase gør Adorno op med, idet han godt nok er pinlig bevidst om, at allerede sproget som rationel diskurs, so oder so, ligger indenfor det almenes sfære, og desuden er det altafgørende kommunikationsmedium. Men for det første forudsætter og livnærer sproget sig af noget, der ligger udenfor sproget selv, nemlig 'livet', og for det andet er den rationelle diskurs kun topppen af det isbjerg, som den sproglige struktur udgør; som æstetisk medium, som fantasimateriale og det ubevidstes kampplads er der også et 'mere'. Uden at 
prisgive myndigheden eller reflektiviteten er det "tænkningens opgave at besinde sig på sig selv" og aldrig glemme, at den ikke er alene i verden, at den kun kan være tænkning over eller om Noget, nemlig det ikke-identiske, det levende og levede liv i al sin mangfoldighed:

"Uden identitetstese er dialektiken ikke det hele; derved er det heller ikke kardinalsynd at forlade den $i$ et dialektisk skridt. Det ligger $i$ den negative dialektiks bestemmelse, at den ikke hviler i sig selv, som var den total; det er dens gestaltning af håbet".

"Ingen Væren uden det Værende". Det 'Noget', der er begrebets tankenødvendige substrat, også for Væren(-sbegrebet), er det yderste, og ikke til at bortskaffe som et med tænkningen ikke-identisk sagsforhold gennem en videre tankeproces; uden dette Noget kan formal logik ikke blive tænkt. Den (formale logik) er ikke til at rense fra sit metalogiske rudiment."

T.W. Adorno: Negative Dialektik. Frankfurt a.m. 1980, s. 398 og 139

Når Adorno andre steder paradoksalt taler om at forsøge at "udsige det uudsigelige", så er paradokset tilsigtet. Han tror ikke virkelig at kunne udsige det. I stedet vil han forsøge gennem en bestemt prismatisk skrivestil eller en æstetisk form at koble læseren med $i$ en associationsrække, en flydende strøm af tanker og sansebilleder, der ikke lader sig sætte på begreb, men som ikke desto mindre er det 'substansielle' grundlag, hiin enkelte reflekterer udfra, og som motiverede reflektionen. Denne flydende strøm af tanker og sansebilleder udgør den subkutane erfaringsgehalt, som al refleksion - selv den videnskabelige - livnærer sig af. Med en sådan antiautoritær nivellering og afhierakisering af de menneskelige livs- og erfaringsformer, der livet igennen gjorde Adorno til en fremmed i det tyske universitetsliv, så er det klart, at der principiel ikke er nogen stoflig afgrænsning for den kritiske tænkning, kun en subjektiv knyttet til den intellektuelles egne forudsætninger. Denne eksplosion af de traditionelle vidensfelter og organiseringer har $\mathrm{N} / \mathrm{K}$ arvet til fulde.

Hvad, der imidlertid synes at falde dem tungere for brystet, er Adornos "billedløse" materialisme. Adorno nedsætter et 'taleforbud' overfor at angive mere positivt, hvad der udgør dette subkutane erfaringsgehalt. Som den jødiske Kabbala-mystik, der ikke må benævne guddommen ved dets navn, nægter Adorno på nogen måde at navngive eller anticipere utopier, og i særdeleshed gør han op med enhver "Ursprungs-filosofi", der taler om oprindelighed, menneskelig væsen som noget konstant iboende osv. Kun negativt, som kompromisløs kritik, kan man tjene det sande menneskelig fremskridt. I den uforsonelige, næsten hadske, tænkning ligger provokationen til at tænke, at "det må kunne være anderledes". 
I forhold til hans diktum om at 'udsige det uundsigelige' ligger der et åbent spørgsmål tilbage, som synes at være det 'hul', som N/K forsøger at udfylde, nemlig om der ikke findes andre kommunikations- og formidlingsformer end den diskursivt-rationelle. Måske ville Adorno selv have afvist det som utilladelig spekulation at forsøge at positivere eller udsige dette kontinent - i alle fald forbliver han tavs. Ikke desto mindre peger hans æstetik, hans begreber om mimesis og det autentiske kunstværk henimod nogle non-verbale eller ekstra-verbale erfaringsområder, der ikke kan affejes som privatistisk indsnævrede, men levende deres liv som fælleseje. Tungens taleforbud er netop betinget af hovedets billedrigdom.

Men dette erfaringsområde unddrager sig altså det almene og instrumentelles domæne. Det forekommer at være præcis på dette sted, at N/K lægger afstand til Adorno.

På den ene side afgrænser de sig overfor en Lenin, der hævder "dialektikken som revolutionens algebra", dvs. dialektikken som en fremadskridende drivkraft, der sikrer det realhistoriske fremskridt, og som er forbundet med større fornuft, frihed osv; det er en bevægelse fra et lavere til et højere stadium. Dialektiken har her en positiv normativ kulør.

Heroverfor står Adorno, der strengt afgrænser dialektikken til at være en ubønhørlig kritik af alt bestående; enhver forestilling om det borgerlige samfund, der forholder sig affirmativt til denne orden som værende naturlig, uforanderlig, fornuftig osv. skal opløses og kritiseres i sin ideologiske form tillige med det samfund, som de er et produkt af. Udover denne kritik må dialektikken ikke gå. Den type immanent kritik, Adorno foretræder, foregår uden billeder, dvs. uden et positivt, etableret alternativ, fordi enhver sådan postuleret utopi selv kan gøres til genstand for kritik (som værende bornert, repressiv eller allerede refleksbestemt og derfor integreret $i$ det totalforvaltede samfund).

Op imod de to dialektik-konceptioner hævder $\mathrm{N} / \mathrm{K}$, at ingen af dem rammer det, som udgør deres egen 'substansielle' eller materielle kærne, det grundlag, hvorpå de selv hviler. Såvel produktionen af affirmative billeder (Lenin), som billedforbudet (Adorno) er utilstrækkelige. Afspejlingsteorien afbilder blot det borgerlige samfunds resultater uden at investere kritisk interesse $i$ de menneskelige arbejds- og livsevners processer og sammenhænge. I sin angst for det instrumentelles gramsen og overgreb forbliver imidlertid også billedforbudets tavshed en halvkvædet vise. I sine konsekvenser bliver begge dialektik-konceptioner 'genstandsløse' og for rationalistiske.

Genstandsløse, forsåvidt de ikke har noget grundlag for en radikal anderledes samfundsorganisering, og tillige rationalistisk, fordi, subkutane 'alogiske' erfaringsområder forties. Herudfra affødes også den para- 
doksale konsekvens, at begge dialektik-konceptioner,forbliver indspundet $i$ en normativ (metafysisk?) retningsbestemmelse af dialektikken som henholdsvis fremskridtsoptimistisk og -pessimistisk! For N/K er den kapitalistisk genererede civilisatorik hverken ren negativitet eller positivitet, og det er ikke til at afgøre på forhånd - ud fra et normativt grundlag - hvad der er hvad. Dialektikken opstår ud fra sammenhængenes selvregulerende og kolliderende bevægelser, dvs. den er genstandsnær og peger i mange retninger; den er flerpolet. Derfor kan N/K også hævde om dialektikken som metode, materialistisk værktøj og realproces, at den er indifferent overfor enhver normativitet - hinsides godt og ondt. Dialektikken kan ikke afgøre, hvad der er progressivt eller regressivt, kun hvad der er sammenhængende og ikke-sammenhængende.

Den labile konfrontationslinie mellem selvreguleringssystemerne og den samfundsmæssige prægning er ikke retningsbestemt. Abstrakt og overordnet har man ingen pegefinger at orientere sig efter med henblik på at skille mellem destruktions- og emancipationsprocesser. Kun som flydende bestemmelser, der henter sin erkendelsesfylde i massage med det konkrete stof, kan der etableres orienteringer for en emancipatorisk fordring. Frigørings-snakken er altså ikke overhalet, den må differensieres. Den kan ikke længer stilles abstrakt punktuelt eller overordnet, sådan som Lenin eller Adorno gjorde det. 